\title{
Phytochemical Screening And Antidiabetic, Antihyperlipidemic Properties Of Leaves Of Filicium Decipiens In Streptozotocin Induced Diabetic Rats
}

\author{
Akila Elias*1, Geetha Priya C1 \\ *1 Department of Pharmacognosy, RR College of Pharmacy, Banglore - 90, Karnataka. \\ ${ }^{1}$ Department of Pharmaceutical Chemistry, RR College of Pharmacy, Banglore - 90.
}

\begin{abstract}
The Present study was undertaken with a view to evaluate the Phytochemical \& Pharmacological activities of the leaves of Filicium decipiens (Sapindaceae). The shade dried powdered plant material was subjected to successive soxhlet extraction with Petroleum Ether, Chloroform, Ethyl acetate and Ethanol. The various extracts were then subjected to preliminary phytochemical screening which revealed the presence of flavanoids, saponins, tannins, phenols, sugars, lipids, alkaloids \& steroids. Selection of active extract for in vivo studies was based on preliminary phytochemical tests and in vitro glucose diffusion inhibition potential and accordingly ethanolic and chloroform extracts were chosen for further studies. Pharmacological screening included evaluation of antidiabetic and hypolipidemic activity of chloroform and ethanolic extracts (200 mg/kg b.w) on Streptozotocin induced diabetic rats. The ethanolic extract was found to be more effective and brought about significant antidiabetic \& hypolipidemic potential. This was due to the presence of one or more phytoconstituents present in ethanol extract. Thus, the present study validates the traditional claim of the plant and endorses a scientific proof in future.
\end{abstract}

Keywords: Filicium decipiens, antidiabetic, hypolipidemic activity.

Article Info: Received 23 June 2019; $\quad$ Review Completed 11 Aug 2019; $\quad$ Accepted 19 Aug 2019; Available online 15 Sep 2019

Cite this article as:

Akila E, Geetha Priya C, Phytochemical Screening And Antidiabetic, Antihyperlipidemic Properties Of Leaves Of Filicium Decipiens In Streptozotocin Induced Diabetic Rats, Journal of Drug Delivery and Therapeutics. 2019; 9(5):62-66 http://dx.doi.org/10.22270/jddt.v9i5.3516

*Address for Correspondence:

Mrs Akila Elias, Asst.Professor, Department of Pharmacognosy, RR College of Pharmacy, Banglore - 90, Karnataka. India.

\section{INTRODUCTION}

Diabetic mellitus is a metabolic disorder characterised by fast evaluation of blood sugar level and it is on a dangerous rise all over the world, especially in Asiatic countries. There is a steady rise in the rate of incidence of diabetes mellitus worldwide. It is estimated that 1 in 5 may be diabetic in 2025. Diabetes in India is slowly changing into a killer disease next to coronary cardiovascular disease. Insulin dependent diabetes mellitus (IDDM) accounts for greater than $10 \%$ of people with diabetes whereas NIDDM is the most common one representing $85 \%$ of all diabetic patients. This disease manifesting in the form of silent epidemic is increasing at a very fast rate with estimated 80 million diabetes in the world today. ${ }^{1}$. Synthetic drugs are likely to give serious side effect in addition they are not suitable for intake during conditions like pregnancy. Hence search for a new drug with low cost to enable poor patients, more potential to focus on future generations without adverse effects for all the diabetic patient of the world, is being pursued in several laboratories all over the world.

A large number of plants in India have been traditionally used for in the treatment of diabetis. Some plants like
Gymnema sylvestris, Coccinia indica, Momordica charandia, Phyllanthus emblica, Murraya koengii,Trigonella foenum graceum, Syzygium cumini, Cassia auriculata and Madhuka latifolia have excellent hypoglycaemic properties and many successful claims have been made on these plants. ${ }^{2}$ Remarkable work has been done at CDRI (Central drug research institute, Lucknow) on clinical scrutiny of antibiotic plants. Excellent work have been done on Pharmacological activities of plants like Aegle marmelos, Ginseng radix, Enicostemma littorole, Cyamopsis tetragonaloba, Momordica charankia, Salacia prenoides and have been successful in proving antidiabetic activities of potential drugs mentioned in old Ayurvedic texts and literature.

Eventhough varying levels of activity have been reported in various plants, it is difficult to claim the best plant for treating diabetes. Filcium decipiens is one such amazing plant with promising folklore claims, Hence, in the present study an attempt was made to evaluate antidiabetic, hypolipidemic activity of the leaves of Filicium decipiens Thw., 


\section{MATERIAL AND METHODS}

\subsection{Plant Material}

The leaves of plant of Filicium decipiens Thw., were collected from Tirunelveli district, Tamilnadu. The plant was identified and authenticated by Prof. P. Jayaraman, Ph.D (PARC/2012/1152), The shade dried leaves were coarsely powdered and used for further studies.

\subsection{Preliminary Phytochemical Screening}

Extraction was performed by successive soxhlet extraction of coarsely powdered leaves of Filicium decipiens Thw, with different solvents in increasing polarity viz., Pet.Ether, Chloroform, Ethyl Acetate, Ethanol. Each extract was concentrated by distilling off the solvent and evaporated to dryness and the Phytochemical screening has been done to identify the presence of secondary metabolites in according to the Harborne methods. ${ }^{3}$

\subsection{Selection of Active Extract}

There has been enormous interest in the development of alternative medicine for type 2 diabetes, especially screening of phytochemicals with the ability to delay or prevent glucose absorption. The goal of the present study was to provide in vitro evidence for potential inhibition of glucose absorption. Various extracts were examined at a concentration of $50 \mathrm{~g}$ plant extract/litre using an in vitro method to assess the possible effects on glucose diffusion across the gastrointestinal tract. The extracts with highest inhibitory effect on glucose diffusion were selected for the in vivo study.

\subsection{In Vivo Antidiabetic Activity4-8}

Healthy Wistar Albino rats (Weighing about 150-200g) were procured from Madras Medical College Animal House. The entire process was approved by the Institutional Animal Ethical Committee which is certified by the Committee for the purpose of Control and Supervision of Experiments on Animals, India CPCSEA (Reg. No.22/243. Dated 10/08/2011).. For experimental purpose the animals were kept fasting overnight but allowed for access to water. The rats were injected intraperitonially with streptozotocin dissolved in citrate buffer of $\mathrm{pH} 4.5$ at a dose of $55 \mathrm{mg} / \mathrm{kg}$ body weight. After 48 hours rats with blood glucose level above $250 \mathrm{mg} / \mathrm{dl}$ were selected for the study.

For the study, the animals were randomly divided into 5 groups of six animals each after the Induction of diabetes.

Group 1: Non diabetic control rats received 1\% CMC, $1 \mathrm{ml}$ orally once daily for 4 weeks.

Group 2: Diabetic control rats received 1\% CMC, $1 \mathrm{ml}$ orally once daily for 4 weeks.

Group 3: Diabetic rats received standard drug Glibenclamide $3 \mathrm{mg} / \mathrm{kg}$ body weight, in $1 \%$ CMC orally once daily for 4 weeks

Group 4: Diabetic rats given ethanolic leaf extract $200 \mathrm{mg} / \mathrm{kg}$ body weight of Filicium decipiens Thw., made a fine suspension with $1 \%$ CMC orally for 4 weeks.

Group 5: Diabetic rats given chloroform leaf extract $200 \mathrm{mg} / \mathrm{kg}$ body weight of Filicium decipiens Thw., made a fine suspension with $1 \%$ CMC orally for 4 weeks.

\subsubsection{Biochemical analysis}

2.4.1.1 Determination of blood glucose levels (Chronic study)

Animals were fasted for 16 hours prior to drug administration allowing access only to water. Blood samples were collected from the retro orbital plexus of the rats at the end of 1,2, 3 and 4th week (Chronic study). Samples were analysed for blood glucose content by GOD-POD method. Other parameters like Serum Total protein, Albumin, Creatinine, Urea, Total bilirubin, SGOT, SGPT, ALP.

\subsubsection{Hypolipidemic Activity $9-11$}

\subsubsection{Determination of lipid profile and lipoproteins}

At the end of the study, blood samples were collected from retro orbital plexus into universal non-heparinised tubes. Allowed it to clot in air, which was later centrifuged at $5000 \mathrm{rpm}$ for 5 minutes and serum separated to proceed analysis. Initial and final body weights were analysed. Serum levels of the following tests were determined by Auto analyser in the biochemical laboratory of Madras Medical College, Chennai. Parameters like Total Cholesterol (TC), Serum Triglycerides (TG), Low Density Lipoprotein (LDL), High Density Lipoproteins (HDL), and Very Low Density Lipoproteins (VLDL) were estimated.

\subsubsection{Histopathological Study 12,13}

At the end of the study, all the animals were sacrificed by cervical displacement method. The whole pancreas from each animal was removed and was collected in $10 \%$ formalin solution, and immediately processed by the paraffin technique. Sections of $5 \mu \mathrm{m}$ thickness were cut and stained by haematoxylin and eosin (H \& E) for histological examination.

\section{RESULTS AND DISCUSSION}

\subsection{Phytochemical Screening}

Qualitative preliminary phytochemical analysis was performed initially with different respective chemical detecting agent to detect the phytoconstituent nature and their presence in each extract and powder. Petroleum ether extract showed the presence of steroids and terpenoids. Chloroform extract was found to contain flavanoids, steroids, tannins, phenols, saponins, terpenoids, Ethyl acetate extract showed the presence of flavanoids, steroids, tannins, phenols, whereas Alkaloids, glycosides, carbohydrates, flavanoids, steroids, tannins, phenols, saponins, terpenoids, were present in Ethanol extract.(Table 1)

\subsection{Selection of Active Extract}

\subsubsection{Effects of Various Extracts on Glucose Diffusion Inhibition Study}

The effect of various extracts on glucose diffusion inhibition was depicted in the (Table 2). At the end of 27 hours, glucose movement of control (without plant extract) in the external solution had reached a plateau with a mean glucose concentration above $300 \mathrm{mg} / \mathrm{dl} \quad(308.33 \pm 7.02)$. It was evident from the graph that the ethanol and chloroform extracts were found to be potent inhibitors of glucose diffusion compared to control. The ethanol extract was found to be more potent than chloroform showing the lowest mean glucose concentration of $208.00 \pm 2.64 \mathrm{mg} / \mathrm{dl}$ at the end of 27 hours. Petroleum ether and Ethyl acetate extracts showed poor glucose diffusion inhibition. Thus the ethanol and chloroform extracts were selected for further in vivo studies. 


\subsection{In Vivo Antidiabetic Activity}

3.3.1 Effect of Ethanolic and Chloroform Extract of Filicium decipiens Thw., on Blood Glucose Level:

Various studies show that a number of plant extracts effectively reduced blood glucose levels in Streptozotocin induced diabetic rats. Till date, the antidiabetic activity of leaves of Filicium decipiens Thw., has never been reported.

\subsubsection{Chronic study}

Chronic administration of Filicium decipiens Thw., extracts to Streptozotocin induced diabetic rats for 4 weeks produced a significant blood glucose reduction. A significant reduction was observed right from 1st week by both Chloroform and Ethanolic extracts which was comparable with that of standard drug, Glibenclamide (3mg/kg b.w) At the end of 4 weeks, ethanolic extract produced a significant reduction of $73 \%$ at $(200 \mathrm{mg} / \mathrm{kg} \mathrm{b.w})$ compared to diabetic control. On the other hand, Glibenclamide produced a significant blood glucose reduction of $78 \%(\mathrm{p}<0.05)$ and the chloroform extract brought about $68 \%$ reduction at $200 \mathrm{mg} / \mathrm{kg}$ b.w. The results are displayed in (Table 3)

\subsection{Hypolipidemic Activity}

3.4.1Effect of Chloroform and Ethanolic extracts of Filicium decipiens Thw., on serum lipid profile

Continuous administration of both chloroform and ethanolic extract produced a significant hypolipidemic effect on streptozotocin induced diabetic rats at the end of 4 weeks. Both the extracts produced a significant decrease $(\mathrm{p}<0.05)$ in the level of Total cholesterol. Triglycerides, LDL, VLDL and a significant increase $(\mathrm{p}<0.05)$ in HDL level. The ethanolic extract was found to be more effective compared to chloroform extract. The results are given in (Table 4)

3.4.2 Effect of Chloroform and Ethanolic extracts of Filicium decipiens Thw., on body weight

Diabetic rats had a poor body weight compared to normal rats. At the same time, diabetic rats treated with Filicium decipiens Thw., extracts showed a significant increase in body weight as tabulated in (Table 5). Histopathological Study is carried out at the end of the study which is shown in (Figure.1)

Table1: Preliminary phytochemical screening of dried powdered material and extracts of the leaves of Filicium decipiens Thw.,

\begin{tabular}{|c|c|c|c|c|c|c|}
\hline S.No. & Chemical Constituents & Powder & PE & $\mathrm{CHCl}_{3}$ & Et.Ac & EtOH \\
\hline 1. & Carbohydrates & + & - & - & - & + \\
\hline 2. & Alkaloids & + & $\ldots$ & + & + & + \\
\hline 3. & Steroids & + & + & + & + & + \\
\hline 4. & Glycosides & + & - & - & - & + \\
\hline 5. & Saponins & + & - & + & _- & + \\
\hline 6. & Flavanoids & + & - & + & + & + \\
\hline 7. & Tannins & + & - & + & _ & + \\
\hline 8. & Phenolic Compounds & + & - & + & + & + \\
\hline 9. & Proteins & - & - & - & . & \\
\hline 10. & Amino acids & - & - & - & _ & _ \\
\hline 11. & Gums \& Mucilage & + & - & - & - & + \\
\hline 12. & Terpenoids & + & + & + & - & + \\
\hline
\end{tabular}

Table 2: Effect of various leaf extracts of plant $(50 \mathrm{~g} / \mathrm{l})$ on the movement of glucose out of dialysis tube over $27 \mathrm{hr}$ incubation period

\begin{tabular}{|c|c|c|c|c|c|}
\hline Extract & $\mathbf{1}$ hour & $\mathbf{3}$ hours & $\mathbf{5}$ hours & 24 hours & 27 hours \\
\hline Control (in the absence of extract) & $125.33 \pm 4.50$ & $196.00 \pm 3.60$ & $236.00 \pm 6.55$ & $274.00 \pm 4.58$ & $308.33 \pm 7.02$ \\
\hline Petroleum ether extract (50gram/litre) & $110.66 \pm 4.04$ & $182.00 \pm 1.73$ & $216.66 \pm 7.63$ & $249.33 \pm 4.04$ & $278.33 \pm 3.05$ \\
\hline Chloroform extract (50gram/litre) & $89.33 \pm 4.04$ & $142.33 \pm 3.05$ & $152.66 \pm 7.50$ & $171.33 \pm 8.50$ & $216.00 \pm 3.60$ \\
\hline Ethyl acetate extract (50gram/litre) & $102.66 \pm 9.29$ & $177.66 \pm 4.04$ & $213.33 \pm 7.63$ & $248.66 \pm 5.13$ & $268.00 \pm 7.00$ \\
\hline Ethanol extract (50gram/litre) & $77.00 \pm 2.64$ & $116.00 \pm 3.60$ & $136.00 \pm 6.55$ & $153.33 \pm 7.63$ & $208.00 \pm 2.64$ \\
\hline
\end{tabular}


Table 3: Effects of Chloroform and Ethanolic extracts of the leaves of Filicium decipiens on blood glucose levels in Streptozotocin induced diabetic rats $(\mathrm{mg} / \mathrm{dl})$ - Chronic study

\begin{tabular}{|c|c|c|c|c|c|}
\hline Group & Initial & 1 week & 2 weeks & 3 weeks & 4 weeks \\
\hline Normal & $91.00 \pm 1.41$ & $93.66 \pm 2.73$ & $94.00 \pm 2.36$ & $94.33 \pm 2.50$ & $93.50 \pm 3.27$ \\
\hline Diabetic control & $289.83 \pm 5.91$ & $287.16 \pm 1.72$ & $292.83 \pm 1.16$ & $298.16 \pm 5.19$ & $312.16 \pm 5.41$ \\
\hline $\begin{array}{c}\text { Diabetic + Glibenclamide (3mg/kg) } \\
\text { Diabetic + Ethanolic Ext } \\
(200 \mathrm{mg} / \mathrm{kg})\end{array}$ & $284.66 \pm 1.03$ & $204.33 \pm 1.03$ & $182.50 \pm 1.76^{*}$ & $176.33 \pm 3.26^{*}$ & $163.33 \pm 1.86^{*}$ \\
\hline $\begin{array}{c}\text { Diabetic + Chloroform Ext } \\
(200 \mathrm{mg} / \mathrm{kg})\end{array}$ & $286.66 \pm 1.63$ & $211.83 \pm 1.60$ & $197.16 \pm 1.83^{*}$ & $184.50 \pm 2.25^{*}$ & $172.33 \pm 2.50^{*}$ \\
\hline
\end{tabular}

Values are expressed as mean \pm SD $n=6 \quad * \mathbf{p}<\mathbf{0 . 0 5}$ compared to diabetic control

Table 4: Effect of Chloroform and Ethanolic extract of Filicium decipiens Thw. on serum lipids and lipoproteins

\begin{tabular}{|l|c|c|c|c|c|}
\hline & Total Cholesterol & Triglycerides & HDL & LDL & VLDL \\
\hline Normal & $103.83 \pm 3.54$ & $99.83 \pm 3.06$ & $44.00 \pm 1.54$ & $39.83 \pm 4.07$ & $20.00 \pm 0.63$ \\
\hline Diabetic Control & $218.33 \pm 8.16$ & $176.16 \pm 8.61$ & $32.00 \pm 1.89$ & $151.16 \pm 8.32$ & $35.16 \pm 1.94$ \\
\hline Diabetic + Glibenclamide (3mg/kg) & $112.00 \pm 2.44^{*}$ & $107.16 \pm 2.13^{*}$ & $50.50 \pm 1.04^{*}$ & $41.66 \pm 1.86^{*}$ & $21.50 \pm 0.54^{*}$ \\
\hline Diabetic + Ethanolic Ext (200mg/kg) & $112.50 \pm 5.24^{*}$ & $108.00 \pm 3.03^{*}$ & $48.33 \pm 1.36^{*}$ & $42.66 \pm 5.31^{*}$ & $21.50 \pm 0.54^{*}$ \\
\hline Diabetic + Chloroform Ext $(200 \mathrm{mg} / \mathrm{kg})$ & $116.60 \pm 4.21^{*}$ & $115.66 \pm 4.58^{*}$ & $47.00 \pm 1.26^{*}$ & $45.50 \pm 4.92^{*}$ & $23.00 \pm 0.89^{*}$ \\
\hline
\end{tabular}

Table 5: Effect of Filicium decipiens Thw., leaf extract on body weight in Streptozotocin induced diabetic rats.

\begin{tabular}{|l|c|c|}
\hline \multicolumn{1}{|c|}{ Group } & Initial (g) & Final (g) \\
\hline Normal & $149.66 \pm 8.4$ & $181.00 \pm 5.7$ \\
\hline Diabetic Control & $151.16 \pm 7.9$ & $116.16 \pm 3.7$ \\
\hline Glibenclamide $(3 \mathrm{mg} / \mathrm{kg})$ & $152.83 \pm 6.1$ & $172.83 \pm 2.0^{*}$ \\
\hline Ethanolic Ext $(200 \mathrm{mg} / \mathrm{kg})$ & $149.66 \pm 6.5$ & $170.83 \pm 3.6^{*}$ \\
\hline Chloroform Ext $(200 \mathrm{mg} / \mathrm{kg})$ & $150.00 \pm 6.0$ & $163.33 \pm 3.2^{*}$ \\
\hline
\end{tabular}



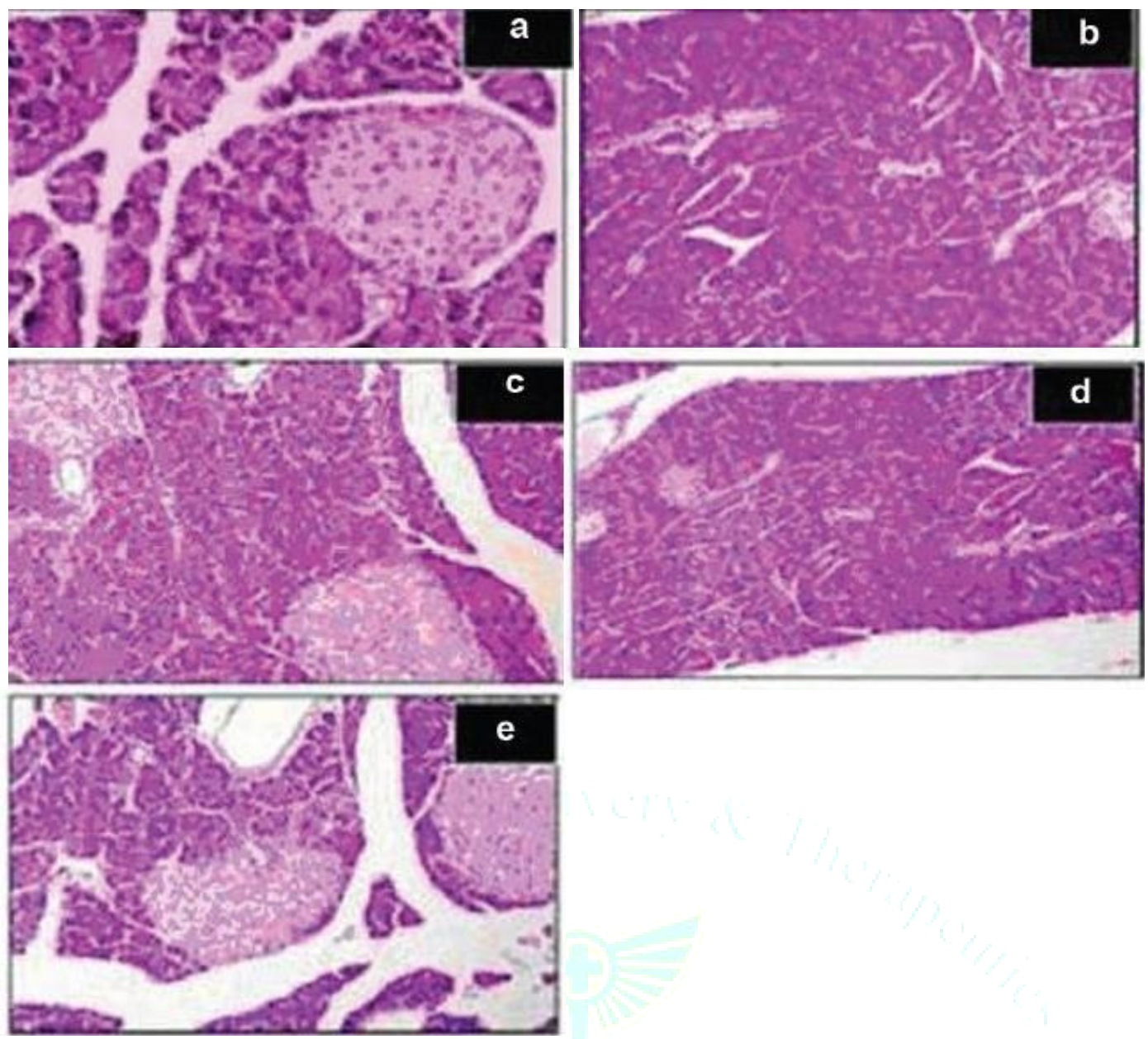

Figure 1: Histopathological study of rat pancreas of Islets of Langerhans

a) Non- diabetic normal histological structure of rat pancreas showing normal islet

b) Diabetic control rat showing irregular cells, not well defined necrosis of cells is very clear

c) Glibenclamide $(3 \mathrm{mg} / \mathrm{kg})$ treated rat pancreas showing mild from STZ induced changes in the pancreatic islets.

d) FDCE (200mg $/ \mathrm{kg}$ ) showed no significant changes in cells were compared with diabetic control FDEE (200mg $/ \mathrm{kg})$ showed slight regeneration of $\beta$ cells were compared with diabetic control

\section{REFERENCES}

1. Awang, D.V.C. Quality control and good manufacturing practices: Safety and efficacy of commercial herbals. Food Drug Law Institute .1997; 52: 341-344.

2. Herb palace, History of Herbal Medicine Available in: www.herb palace.com/alternative medicine/herbal-medicine html. [Accessed on 8/8/2011].

3. J. B. Harborne, Phytochemical Methods, Chapman and Hall, London, UK, 1973.

4. Malini P, Kanchana G, Rajadurai M. Antidiabetic activity of Ellagic acid in Streptozotocin induced diabetes mellitus in albino wistar rats. Asian Journal of Pharmaceutical and Clinical Research. 2011;4(3).

5. Cetto AA, Wiedenfeld H, Revilla MC, Sergio IA. Hypoglycemic effect of Equisetum myriochaetum aerial parts on Streptozotocin diabetic rats. Journal of Ethnopharmacology .2000;72:129-133.

6. Ramakrishna D , Vidyasagar G, Pavan Kumar K, Madhusudhana I, Gupta VSS S. Evaluation of antidiabetic activity of Triumfetta pilosaroth in Streptozotocin induced diabetic rats. International Journal of Pharma Sciences and Research. 2011;2(3): 98-103.

7. Dangi KS, Mishra SN. Effect of Capparis aphylla stem extract treatment in normal and Streptozotocin induced diabetic rats infected with Candida albicans. Asian Journal of Experimental and Biological Sciences. 2011;2(1):107-109.

8. Pattabiraman K, Muthukumaran P. Antidiabetic and Antioxidant Activity of Morinda tinctoria roxb Fruits Extract in
Streptozotocin-Induced Diabetic Rats. Asian Journal of Pharmaceutical Technology.2011; 1(2): 34-39.

9. Zainab M, Thomson M, Khaled K, Shalaby RP. Anti-diabetic and hypolipidaemic properties of ginger (Zingiber officinale) in Streptozotocin-induced diabetic rats. British Journal of Nutrition. 2006; 96: 660-666

10. Virendhra singh, Mahendra singh, Shukla S, Sunil singh Mansoori MH, Kori ML. Antidiabetic effect of Flacourtia indica Merr in Streptozotocin induced diabetic rats. Global Journal of Pharmacology. 2011;5(3):147-152.

11. Vadivelan $R$, Dipanjan $M$, Umasankar $P$, Palaniswami S, Muthureddy D ,Satishkumar N. Hypoglycemic, antioxidant and hypolipidemic activity of Asparagus racemosus on Streptozotocin-induced diabetic in rats. Advances in Applied Science Research. 2011; 2(3): 179-185

12. Jelodar G, Mohsen M, Shahram S. Effect of walnut leaf, coriander andpomegranate on blood glucose and histopathology of pancreas of Alloxan induced diabetic rats. African Journal of Traditional Complementary and Alternative Medicines.2007; 4 (3): $299-305$.

13. Jayasri MA, Gunasekaran S, Radha A, Mathew TL. Anti-diabetic effect of Costus pictus leaves in normal and Streptozotocininduced diabetic rats. International Journal of Diabetes \& Metabolism. 2008; 16: 117-122. 